\title{
Talking about Vocational Ability Cultivation of Higher Vocational Students on Basis of Training and Identification
}

\author{
Tingting Chen \\ Nanjing Institute of Mechatronic Technology \\ Nanjing, China 211135
}

\begin{abstract}
For higher vocational colleges, student employment has been insisted as their ultimate task. Therefore, higher vocational colleges must find ways to improve the students' professional ability, so as to improve student employment rate. In this process, professional skill appraisal has become a need of students' professional ability training.
\end{abstract}

Keywords-basis of training and identification; higher vocational college; professional ability training

\section{INTRODUCTION}

In this paper, besides explaining the importance of occupation skill appraisal, the training principle of students' occupation ability has been provided as follows: take improving students' employment and entrepreneurial ability as the core; take improving students' occupation skill level as the key work; achieve the change from single collages cultivating to combination collages and enterprises cultivating. Furthermore, a training idea has been provided as follows: developing from the talent cultivation mode and theoretical knowledge to post occupation skill decomposition, integrating into core course teaching, then developing to reform ability evaluation model, so as to realize the innovation of students' evaluation mode.

\section{OCCUPATION SKILL APPRAISAL IS NOT ONLY A LINK} BETWEEN EMPLOYER AND HIGHER VOCATIONAL COLLEGE, BUT ALSO A NEED OF CULTIVATING OCCUPATION ABILITY, AS

Well as a GuARANTEE OF MUlTi CERTIFICATE SYSTEM

In order to adapt changes in society under new situation, vocational education should focus on training mode reform of student occupation ability, bond a variety of specific work and occupation skill appraisal together to actively build a training platform for students' occupation comprehensive quality which can be used to carry out evaluation for students' comprehensive quality to broaden students' vocational fields and let students try to get more qualification certificates, so that professional talents who meet the needs both of society and enterprise can be provided.

\section{PRINCIPLE OF STUDENTS' VocATIONAL ABILITY TRAINING}

\section{A. It Is the Core to Improve Student Employment}

As a higher vocational college, the ultimate goal is employment. So it requires higher vocational colleges should strengthen cultivation of students' occupation ability, and then through identification of skills, conveying a large number of talents with professional skills for enterprises, so as to improve students' employment competition ability. At present, the training of occupation ability in higher vocational colleges has been far from the needs of students' present occupation ability. Therefore, higher vocational colleges must be brave to go out, and understand the need of enterprise, then develop corresponding teaching programs and evaluate students' comprehensive quality through occupation skill appraisal, so that students can obtain qualification certificate meeting their vocational plan and have improved employment ability.

\section{B. It Is the Focus of Work in Higher Vocational Colleges to Further Improve Students' Professional Ability}

In order to adapt to education reform under new situation, higher vocational colleges must pay attention to training mode innovation of professional ability, and make full use of specific work such as major setup and teaching and combine with occupation skill appraisal, then cultivate students' professiona skills through advanced teaching mode and methods to provide high-quality technical personnel.

\section{The Training Mode Change From Single Higher}

Vocational College to Integration of College and

Enterprise Which Can Further Improve Professional Skill and Achieve "Order" Training Mode

During this process, enterprises pay for higher vocational colleges, which requires enterprises take part in training teaching. According to the demand of market, product structure and enterprise development, both of college and enterprise arrange teaching programs. As the condition of paying bill, the cultivation of students' professional ability in higher vocational colleges must meet the needs of enterprises. Enterprises, paying bill for higher vocational colleges, not only provide employment jobs and internship jobs, but also provide professional technical talents to higher vocational colleges to teach students, so as to help students to adapt society easily. 


\section{MEASURES OF IMPROVING STUDENTS' PROFESSIONAL TRAINING}

\section{A. For Changing Talent Education Methods in Higher} Vocational Colleges, Students' Practical Ability Should Be Paid Attention To

Usually the training mode of students' ability pays special attention to improve students' comprehensive quality and ability, including e the following aspects: firstly, correctly handle the relationship of students' professional skills and humanistic education, because in addition to professional skills training in higher vocational colleges, humanistic knowledge also is indispensable, which can cultivate students' professional ethics, so as to change the situation of emphasis on professional skills training; Secondly, adhere to combination of classroom learning and extracurricular activities, because in higher vocational colleges, the content of classroom teaching has been difficult to meet students' need of current new knowledge, innovation and ability training, so life specific practice can really improve students' occupation ability. Finally, must adhere to combination of theory and practice, students should make full use of theory knowledge in production practice, which will deepen students' understanding of knowledge, so as to well master theory of skill.

\section{B. Decomposition of Post Professional Skills, Integrating into Core Course}

Taking chemical engineering as an example, in higher vocational colleges, government has formulated appropriate learning content and skill requirements for major of chemical engineering, as well as enterprises also have specific requirements, therefore, colleges should train student in view of enterprises' requirements. At the same time, colleges should fully understand students' actual ability, not only focus on students' score, but also consider students' overall quality in evaluation of quality. After training, the students can accurately grasp the chemical professional skills; after passing the occupation skill appraisal examination, they can get the occupation qualification certificates, and then go to the chemical enterprises to practice and make use of theory knowledge into chemical enterprises, so as to enhance students' employment ability.

\section{Reform Ability Evaluation Model}

Higher vocational colleges have been changing from single graduation certificate to combination of graduation certificate, professional qualification certificate and multiple certificates, and then building the platform of professional ability training and evaluation. The core ability of occupation evaluation mode is employment oriented, which is required maximally reflect the ability of students, therefore, colleges and other units should jointly implement a reform of evaluation model. In reforming of student evaluation model, as a powerful guarantee for certificate, vocational skill appraisal has played an important role in guiding occupation training and strengthening occupation ability of students, which evaluate the overall quality of students using advanced methods according to actual situation. So higher vocational colleges should take innovation of training model, and actively combination with the occupation skill appraisal, so as to enable students to obtain multiple qualification certificates, and further broaden students' occupation field, and get the ability of handling complex social environment.

\section{CONCLUSION}

Under influence of economic market in China, higher vocational colleges must fully realize the importance of professional skill appraisal which can make students' professional ability to be further strengthened, also can effectively ensure students getting more professional qualification certificates, thus shorten the adaptive phase of social posts, therefore, the employment rate will be greatly improved. In future, higher vocational colleges should continue to increase vocational skills appraisal to let more students get their required qualification certificate, so as to improve students' comprehensive quality, and strive to do a good job by the school to cultivate students' ability, and take the change from single occupation school training to integration of enterprise and higher vocational teaching mode, cultivate talents meeting demands of social enterprises.

\section{REFERENCES}

[1] Chen Chunhui. Discussion on Vocational Ability Cultivation of Students of Higher Vocational School Under The Perspective of Vocational Training and Skill Appraisal [J]. Human Resource Management .2016, (02): 12_16.

[2] Wang Xinnian, Xing Lei. Research on Integrated Application of Practical Teaching and Skill Identification [J]. Northern Economy .2012, (06): 61_68.

[3] Zhan Guiying. Study on the Method of Vocational Ability Cultivation of the Students of Higher Vocational School [J]. Brand .2014 (3): 8_9. 